\begin{tabular}{|c|c|}
\hline NIBR & Management and Business Revie \\
\hline $\begin{array}{c}\text { MANAGEMENT \& } \\
\text { BUSINESS REVIEW } \\
\end{array}$ & $\begin{array}{l}\text { Available at http://ejournal.unikama.ac.id/index.php/mbr } \\
\text { ISSN: 2541-5808 (online) }\end{array}$ \\
\hline
\end{tabular}

\title{
Efektifitas kebijakan makroprudensial dan suku bunga SBI terhadap risiko kredit perbankan di Indonesia
}

\author{
Maria Febriyati Campos \\ Program Studi Manajemen, Fakultas Ekonomika dan Bisnis, Universitas Kanjuruhan Malang, \\ Indonesia \\ e-mail: vettycampoz@gmail.com
}

$\begin{array}{ll}\text { Article Info: } \\ \text { Receive } & \text { : April, } 2019 \\ \text { Revised } & : \text { Mei, } 2019 \\ \text { Accepted } & \text { : Juni, } 2019 \\ \text { Published } & : \text { Juni, 2019 } \\ \text { DOI } & : \text { 10.21067/mbr.v3i1.4733 } \\ \text { Copyright } & : \text { Management and } \\ & \text { Business Review }\end{array}$

Keywords:

Risiko Kredit, Capital Buffer, GWM LFR, suku bunga SBI

\begin{abstract}
The research objective was to assess the effectiveness of macroprudential policies, namely Capital Buffer and GWM Loan to Funding Ratio and macroeconomic factors as measured by SBI interest rates on bank credit risk in Indonesia. Research samples of banking companies that go public, with the 20122016 study period. This type of quantitative research with an explanatory research approach is to analyze the effectiveness of the variable Capital Buffer, GWM Loan to Funding Ratio and SBI interest rates on bank credit risk. The sampling technique uses purposive sampling, the analysis technique uses multiple linear regression analysis. The results showed that Capital Buffer, GWM Loan to Funding Ratio and SBI interest rates effectively had an effect on credit risk. This study only uses a five-year period, for further research it should add to the research period, and can add a loan to value (LTV) variable.
\end{abstract}

Abstrak: Penelitian bertujuan untuk menilai keefektifan dari kebijakan makroprudensial yaitu Capital Buffer dan GWM Loan to Funding Ratio serta faktor makroekonomi yang diukur dengan suku bunga SBI terhadap risiko kredit perbankan di Indonesia. Sampel penelitian perusahaan perbankan yang go public, dengan periode penelitian tahun 2012-2016. Jenis penelitian kuantitatif dengan pendekatan eksplanatory research yaitu menganalisis efektifitas variabel Capital Buffer, GWM Loan to Funding Ratio dan suku bunga SBI terhadap risiko kredit perbankan. Teknik pengambilan sampel menggunakan purposive sampling, teknik analisis menggunakan analisis regresi linier berganda. Hasil penelitian menunjukkan bahwa Capital Buffer, GWM Loan to Funding Ratio dan suku bunga SBI secara efektif berpengaruh terhadap risiko kredit. Penelitian ini hanya menggunakan periode lima tahun, untuk penelitian selanjutnya hendaknya menambah periode penelitian, dan dapat menambahkan variabel loan to value (LTV) 


\section{Pendahuluan}

Sektor keuangan di Indonesia didominasi oleh perbankan, sehingga bila terjadi guncangan pada perbankan maka akan berdampak pada sektor keuangan secara keseluruhan. Pada dasarnya bank merupakan lembaga yang menghimpun dana dari masyarakat dalam bentuk simpanan dan menyalurkannya kembali kepada masyarakat secara individu maupun kelompok. Pada saat bank menyalurkan kredit, saat itu pula bank dihadapkan dengan risiko, yaitu berupa risiko kredit. Risiko kredit timbul karena kemampuan manajemen kredit yang kurang berhati-hati. Indikator yang seringkali digunakan untuk mengetahui risiko kredit yaitu Non Performance Loans (NPL). Semakin tingginya Non Performance Loans (NPL) suatu bank menunjukkan risiko yang semakin tinggi. Upaya yang dilakukan Bank Indonesia agar sektor keuangan di Indonesia yang di dominasi oleh perbankan sehat dan kuat serta tahan dalam menghadapi risiko kredit dan likuiditas yaitu dengan berlakukan kebijakan makroprudensial (Swaningrum \& Hariwan, 2014).

Istilah makroprudensial mulai muncul sejak pemulihan krisis keuangan Asia pada akhir 1990-an dan menjadi perhatian sejak terjadinya krisis keuangan global 2008. International Monetary Fund (IMF) kebijakan makroprudensial adalah kebijakan yang memiliki tujuan utama untuk memelihara stabilitas sistem keuangan secara keseluruhan melalui pembatasan peningkatan risiko sitemik. Tujuan utama kebijakan makroprudensial adalah mencegah terjadinya guncangan terhadap guncangan terhadap stabilitas ekonomi. Oleh karena itu, seluruh kebijakan diarahkan untuk mencermati risiko sistemik disektor keuangan, termasuk mencegah terbentuknya risko kredit akibat terseret pertumbuhan yang terlampau cepat.

Negara-negara yang sedang berkembang menggunakan instrumen makroprudensial lebih luas dibandingkan negara-negara maju (Antipa et al., 2010). Indonesia merupakan salah satu negara berkembang dimana sektor keuangan didominasi oleh perbankan, sehingga bila terjadi guncangan pada perbankan maka akan berdampak pada sektor keuangan secara keseluruhan. Jika melihat ketidakseimbangan sektor perbankan di Indonesia pada saat krisis, sektor keuangan di Indonesia tidak bisa menilai, meminimalisir dan memitigasi risiko kegiatan usahanya sehingga menciptakan prosiklikalitas yang berlebihan.

Prosiklikalitas perbankan merupakan perilaku penyaluran kredit bank yang berlebihan sehingga mendorong perekonomin tumbuh lebih cepat ketika kondisi ekspansi dan mempercepat penurunan kegiatan ekonomi ketika dalam keadaan kontraksi (Ardely \& Syofyan, 2016).

Di indonesia instrumen kebijakan makroprudensial untuk mengatasi masalah dan mempertahankn kondisi ekonomi perbankan dalam menghadapi risiko kredit dan likuiditas yaitu Capital Buffer dan GWM LFR. Pembuat kebijakan memilih 
instrumen ini karena sederhana, efektif dan mudah diimplementasikan dengan distorsi pasar yang paling kecil.

Tujuan penelitian untuk menganalisis pengaruh variabel instrumen kebijakan makroprudensial Capital Buffer dan GWM LFR (Loan to Funding Ratio) serta faktor makro ekonomi suku bunga SBI terhadap risiko kredit perbankan di Indonesia.

\section{Risiko Kredit}

Risiko kredit sebagai kemungkinan kehilangan outstanding loan sebagian atau seluruhnnya, karena kegagalan dalam mengelola kredit (Goodhart, 2011). Greuning \& Bratanovic (2009) menjelaskan bahwa hampir semua regulator menetapkan standar pengelolaan risiko kredit meliputi identifikasi risiko dan potensi yang ada, menetapkan aturan mengenai ukuran/parameter dalam risiko kredit yang akan dikontrol.

Indikator yang digunakan untuk mengetahui risiko kredit berupa Non Performance Loan (NPL) (Haryanto, 2015). NPL yang besar cenderung tidak efisien. Besarnya NPL yang diperbolehkan Bank Indonesia saat ini adalah maksimal 5\%. Semakin tinggi nilai NPL suatu bank menunjukkan risiko yang semakin tinggi pula.

\section{Makroprudensial}

Kebijakan makroprudensial adalah kebijakan yang ditujukan untuk meningkatkan ketahanan sitem keuangan dan untuk memitigasi risiko sistemik yang timbul akibat keterkaitan antar institusi dan kecenderungan institusi keuangan untuk mengikut siklus ekonomi sehingga memperbesar risiko sistemik (Ferguson, 2010).

Instrumen makroprudensial digunakan untuk memitigasi tiga kategori dalam risiko sitemik, yaitu resiko-resiko yang ditimbulkan akibat pertumbuhan kredit yang terlalu kuat, risiko likuiditas dan risiko akibat arus modal masuk yang deras (Angelini et al., 2011).

\section{Kebijakan Capital Buffer}

Capital Buffer didefinisikan sebagai selisih lebih antara rasio kecukupan modal (CAR) yang dimiliki perbankan dengan persyaratan minimum modal perbankan yang diberlakukan regulator (Anggitasari \& Arfinto, 2013). Capital Buffer menjadi pelindung yang dapat menyerap berbagai risiko yang muncul, jika financial distress cost dari modal yang rendah, serta biaya akses modal baru yang tinggi. Capital Buffer merupakan selisih antara besarnya CAR bank dengan ketentuan CAR dari Bank Indonesia yaitu sebesar $8 \%$. Berdasarkan pentingnya permodalan bagi bank, maka bank tidak hanya berusaha untuk memenuhi ketentuan minimal CAR, tetapi bank berusaha memperbesar CAR di atas minimum. CAR bank diatas minimum berfungsi apabila bank ingin memitigasi risiko dari siklus binis yang ada (Haryanto, 2015). Salah satu risiko perbankan 
adalah risiko kredit yang diukur dengn NPL. Dimana semakin tinggi nilai NPL maka akan mengurangi modal pada perbankan.

Hasil penelitian yang dilakukan oleh Haryanto (2015) dan Lim et al. (2011) menunjukkan bahwa Capital Buffer berpengaruh terhadap risiko kredit dan hasil penelitian Anggitasari \& Arfinto (2013) secara simultan NPL berpengaruh positif tetapi tidak signifikan terhadap Capital Buffer.

\section{Kebijakan GWM LFR (Loan to Funding Ratio)}

Sebelum diberlakukannya peraturan GWM LFR, Bank Indonesia menggunakan GWM LDR untuk mengukur tingkat likuiditas perbankan. Peraturan ini mengalami perubahan pada tahun 2015 yaitu diganti dengan Loan to Funding Ratio (LFR). Hal ini dilakukan Bank Indonesia agar perbankan memiliki ruang yang lebih besar untuk menyalurkan kreditnya, karena sumber pendanaannya tidak hanya dari DPK tetapi juga surat-surat berharga yang diterbitkan bank itu sendiri. GWM LFR merupakan simpanan minimum rupiah yang wajib dipelihara oleh bank dalam rekening giro di bank sentral sebesar presentase tertentu dari DPK yang dihitung berdasarkan selisih antara realisasi LFR bank dan LFR target yang ditetapkan BI. Berdasarkan peraturan Bank Indonesia No. 19/6/PBI/2017 target LFR perbankan Indonesia sebesar 80-92\%.

Penelitian terdahulu menggunakan GWM LDR dengan hasil yang menunjukkan bahwa istrumen kebijakan makroprudensial berpengaruh secara efektif dalam mengurangi prosiklikalitas kredit (Lim et al., 2011; Nuryana, 2017; Purnawan \& Nasir, 2015; Tovar Mora et al., 2012). Namun penelitian ini tidak sejalan dengan penelitian yang dilakukan oleh Emyliani et al. (2018) yang menyatakan bahwa instrumen GWM LDR belum secara efektif mengatasi prosiklikalitas kredit.

\section{Suku Bunga SBI}

Sertifikat bank Indonesia SBI adalah surat berharga atas unjuk dalam rupiah yang diterbitkan oleh bank Indonesia. Suku bunga SBI merupakan tingkat suku bunga rill yang dikeluarkan oleh Bank Indonesia (Abdullah \& Tantri, 2012).

Sejak awal Juli 2005, Bank Indonesia menggunakan target suku bunga SBI yang digunakan untuk pelelangan pada masa periode tertentu yaitu BI Rate, yang mana digunakan sebagai acuan para investor dalam mengikuti pelelangan. Pada tanggal 19 Agutus 2016 Bank Indonesia memperkenalkan suku bunga acuan atau suku bunga kebijakan baru yaitu BI 7-Day Repo Rate. Berdasarkan hasil penelitian yang dilakukan oleh (Dewi \& Ramantha, 2015) menunjukkan bahwa suku bunga SBI berpengaruh positif terhadap risiko kredit yang diukur dengan NPL, berbeda dengan penelitian yang dilakukan (Sintya \& Santi, 2015) menunjukkan suku bunga SBI berpengaruh tidak signifikan dan negatif terhadap NPL. 


\section{Hubungan Capital Buffer terhadap risiko kredit.}

Kebijakan Capital Buffer yang memiliki tujuan untuk mengantisipasi peningkatan kerugian di masa depan dan melindungi bank apabila terjadi guncangan risiko di masa yang akan datang. Bank akan selalu dihadapkan pada risiko, salah satu risiko bank adalah berupa risiko kredit. Risiko kredit bank diproksikan dengan NPL, dimana semakin tinggi NPL maka akan menggerogoti permodalan bank. Sehingga ketika permodalan bank (CAR) semakin kecil akan membuat Capital Buffer bank akan juga akan semakin kecil. Semakin tinggi Capital Buffer maka risiko kredit semakin kecil karena bank mempunyai dana yang cukup besar untuk mengatasi risiko tersebut. Sebaliknya jika Capital Buffer semakin kecil maka akan meyebabkan tingginya risiko kredit karena bank tidak memiliki dana yang besar untuk mengatasi risiko itu (Haryanto, 2015).

$H_{1}$ : Capital Buffer berpengaruh negatif terhadap risiko kredit.

\section{Hubungan GWM LFR terhadap risiko kredit.}

Tujuan dari GWM LFR (Loan to Funding Ratio) adalah untuk meningkatkan ketahanan sektor perbankan dalam menghadapi berbagai risiko khususnya terkait dengan risiko kredit dan likuiditas sehingga dapat mendukung stabilitas sistem keuangan sekaligus stabilitas moneter melalui penguatan peran intermediasi bank (SE BI No.18/18/DKMP tanggal 22 Agustus 2016). GWM LFR dalam rupiah ditetapkan dengan parameter kisaran LFR target adalah 80-92\% dengan GWM utama $8 \%$. Jika perbankan memiliki LFR dibawah batas minimum $80 \%$ maka perbankan dikatakan tidak likuid dalam memenuhi kewajibannya, sebaliknya perbankan yang memiliki LFR diatas batas maksimum 92\% maka akan diikuti oleh risiko kredit yang tinggi. Jadi semakin tinggi nilai LFRnya makan semakin tinggi pula risiko kreditnya.

$\mathrm{H}_{2}$ : GWM LFR berpengaruh negatif terhadap risiko kredit.

\section{Hubungan Suku bunga SBI terhadap risiko kredit.}

SBI merupakan instrumen yang paling disenangi oleh perusahaanperusahaan lembaga keuangan karena dianggap paling aman dan memberikan cadangan likuiditas sekunder yang dapat memberikan kepastian hasil (Anggitasari \& Arfinto, 2013). Perubahan kenaikan suku bunga SBI akan mengakibatkan perbankan akan menaikan pula suku bunga depositonya. Dengan naiknya suku bunga deposito maka biaya yang dikeluarkan perbankan untuk menghimpun dana pihak ketiga juga meningkat, sehingga biaya dana (cost of fund) perbankan akan meningkat. Jika ini terjadi maka suku bunga pinjaman perbankan juga akan meningkat sehingga kemungkinan terjadinya pinjaman bermasalah (Non Performance Loans/NPL) semakin besar.

$H_{3}$ : Suku bunga SBI berpengaruh positif terhadap risiko kredit 


\section{Metode}

Penelitian merupakan jenis explanatory research, untuk menguji hubungan kausal antar variabel. Populasi penelitian adalah perbankan yang go public di Bursa Efek Indonesia. Teknik pengambilan sampel yang digunakan adalah puposive sampling, dengan kriteria: Bank konvensional masih beroperasi hingga 2017; telah go public di Bursa Efek Indonesia sebelum tahun 2013; mempublikasikan laporan tahunan yang lengkap selama periode 2013-2017. Berdasarkan kriteria tersebut maka diperoleh sampel sebanyak 25 perbankan. Sumber data yang digunakan data sekunder yang bersumber dari www.sahamok.com dan www.idx.co.id. Jenis data berupa data kuantitatif berupa data laporan keuangan tahunan (annual report), dan tingkat bunga SBI yang diperoleh dari data www.bi.go.id. Teknik analisis data dilakukan dengan Regresi Linear Berganda, dengan variabel independennya yaitu Capital Buffer, GWM LFR dan suku bunga SBI, sedangkan variabel dependennya yaitu risiko kredit yang diukur dengan NPL.

\section{Hasil}

Hasil uji normalitas dapat dilihat pada nilai Asymp Sig (2-tailed) hasil perhitung Kolmogorov-Smirnov lebih besar dari 0,05 atau 5\% yaitu sebear 0,141 $(14,1 \%)$, hal ini menunjukkan bahwa data terdistribusi normal. Dengan demikian model regresi layak digunakan dalam penelitian. Hasil uji heterokedastisitas diperoleh scatterplot menunjukkan menyebar dan tidak membentuk pola tertentu atau menyebar diatas dan dibawah angka nol pada sumbu studetizes residual atau sumbu $Y$ dan di kanan dan kiri sumbu studetized predicted value yang artinya tidak terdapat gejala heterokedastisitas. Hasil uji multikolinearitas diketahui masingmasing variabel bebas yaitu Capital Buffer (X1), GWM LFR (X2), dan suku bunga SBI (X3) mempunyai nilai tolerancenya tidak ada yang kurang 0,1 dan nilai VIFnya tidak ada yang lebih besar dari 10\%, sehingga dapat disimpulkan bahwa tidak ada multikolinieritas. Dan yang terakhir uji autokorelasi menunjukkan nilai DW sebesar 1,725 yang ditunjukkan pada tabel 5, dengan jumlah data (n) sebnayak 125 dan tabel Durbin-Watson dengan signifikansi 0,05 diperoleh nilai dU 1,7574 dan dL sebesar 1,6592. Nilai DW hitung berada diantara dL 1,6592 dan dU 1,7574 sehingga dapat disimpulkan tidak terjadi autokorelasi.

Hasil uji model dengan Uji F pada tabel 1, menunjukkan bahwa model Regresi dapat menjelaskan perubahan variabel bebas Capital buffer, GWM LFR, dan SBI terhadap NPL. Adapun kemampuan variabel bebas Capital buffer, GWM LFR, dan SBI dalam menjelaskan perubahan NPL bisa dilihat dari nilai koefisien determinasi $R^{2}$ 0,672, artinya variabel bebas Capital buffer, GWM LFR, dan SBI memberikan kontribusi sebesar $67,2 \%$ terhadao perubahan NPL, sedangkan sisanya $32,8 \%$ dijelaskan oleh variabel lain yang tidak termasuk dalam model. 
Management and Business Review, 3(1) 2019, 23-32

Tabel 1. Hasil Analisis Regresi

\begin{tabular}{lcccc}
\hline \multicolumn{1}{c}{ Variabel } & $\begin{array}{c}\text { Koefisien } \\
\text { Regresi }\end{array}$ & $\mathrm{t}$ & Sig & Hipotesis \\
\hline Capital Buffer(X1) & 0,045 & 2,083 & 0,034 & H1 diterima \\
GWM LFR(X2) & 0,076 & 2,123 & 0,021 & H2 diterima \\
SBI(X3) & 0,123 & 2,328 & 0,015 & H3 diterima \\
\hline
\end{tabular}

Dependent Variabel: NPL

Konstanta: 3,697

F Hitung: 4,077

Prob. (Sig): 0,000

$\mathrm{R}^{2}: 0,672$

Sumber : Data Diolah

Koefisien regresi capital buffer sebesar 0,045 dengan nilai signifikan 0,034 menunjukkan bahwa capital buffer berpengaruh positif dan signifikan terhadap NPL, dengan demikian H1 diterima. Koefisien regresi GWM LFR sebesar 0,076 dengan nilai signifikan 0,021 menunjukkan bahwa GWM LFR berpengaruh positif dan signifikan terhadap NPL, dengan demikian H2 diterima. Koefisien regresi SBI sebesar 0,1236 dengan nilai signifikan 0,05 menunjukkan bahwa SBI berpengaruh positif dan signifikan terhadap NPL, dengan demikian H3 diterima.

\section{Pembahasan}

Pengaruh Capital Buffer, GWM LFR dan suku bunga SBI terhadap Risiko Kredit

Hasil penelitian menunjukkan bahwa secara simultan Capital Buffer, GWM LFR dan suku bunga SBI berpengaruh terhadap risiko kredit perbankan. Hal ini menunjukkan bahwa kenaikan atau penurunan Capital buffer, GWM LFR dan suku bunga SBI akan mempengaruhi besarnya risiko kredit perbankan di Indonesia. Variabel yang paling dominan adalah suku bunga SBI yang dapat dilihat dari nilai unstandardized coefficientsnya yaitu sebesar 0,123 lebih besar dari kedua varibel lainnya. Hasil penelitian ini relevan dengan penelitian dari Lim et al. (2011), Tovar Mora et al. (2012) dan Nuryana (2017) yang menyatakan bahwa Capital Buffer, GWM LDR berpengaruh secara efektif terhadap risiko kredit. Hasil analisis data tersebut menunjukan bahwa kenaikan atau penurunan capital buffer, GWM LFR dan suku bunga SBI akan mempengaruhi besarnya risiko kredit perbankan di Indonesia.

\section{Pengaruh Capital Buffer terhadap Risiko Kredit}

Hasil penelitian ini menunjukkan bahwa secara parsial capital buffer berpengaruh positif dan signifikan terhadap risiko kredit. Hal ini menjelaskan bahwa semakin tinggi capital buffer maka semakin tinggi pula risiko kredit perbankan yang diukur dengan NPL. Penelitian ini menolak hipotesis yang menyatakan bahwa capital buffer berpengaruh negatif terhadap risiko kredit. 
Management and Business Review, 3(1) 2019, 23-32

Hasil penelitian ini sejalan dengan Haryanto (2015), Lim et al. (2011) dan Nuryana (2017) yang menunjukkan capital buffer berpangaruh terhadap risiko kredit. Capital Buffer dapat menjadi pelindung/penyerap berbagai risiko yang mungkin muncul, jika financial distress dari modal yang rendah serta biaya akses modal baru yang tinggi.

\section{Pengaruh GWM LFR (Loan to Funding Ratio) terhadap Risiko kredit}

Hasil penelitian menunjukkan bahwa secara parsial semakin tinggi nilai GWM LFR berpengaruh positif dan signifikan terhadap risiko kredit perbankan. Hal ini menunjukkan bahwa GWM LFR maka semakin tinggi pula risiko kredit. Penelitian ini menolak hipotesis yang menyatakan bahwa GWM LFR berpengaruh negatif terhadap risiko kredit. Hasil penelitian ini relevan dengan Purnawan \& Nasir (2015), Lim et al. (2011) dan Tovar Mora et al. (2012) dimana GWM LDR berpengaruh terhadap risiko kredit. Berbeda dengan hasil penelitian yang dilakukan oleh Emyliani et al. (2018) yang menyatakan bahwa GWM LDR tidak berpengaruh dalam mengatasi risiko sistemik pada perbankan konvensional di Indonesia. Alasan lain yang memungkinkan terjadinya perbedaan hasil penelitian ini aalah perbankan mempunyai cara sendiri dalam menyerap risiko kredit, seperti dengan pembagian risiko gagal bayar dengan membagi kepada para investor dan pemegang saham.

\section{Pengaruh Suku bunga SBI terhadap Risiko Kredit}

Hasil penelitian menunjukkan bahwa secara parsial suku bunga yang diukur denagn SBI berpengaruh positif dan signifikan terhadap risiko kredit perbankan. Hal ini menjelaskan bahwa SBI mampu dijadikan sebagai pelindung dari risiko kredit perbankan di Indonesia, yang mana semakin tinggi tingkat suku bunga SBI semakin tinggi juga tingkat suku bunga deposit dan suku bunga pinjaman perbankan sehingga kemungkinan terjadinya pinjaman bermasalah atau risiko kredit semakin besar. Penelitian ini menerima hipotesis yang menyatakan bahwa Suku bunga SBI berpengaruh positif terhadap risiko kredit.

Hasil penelitian ini relevan hasil penelitian dengan Dewi \& Ramantha (2015) yang menyatakan bahwa adanya pengaruh positif variabel suku bunga SBI terhadap NPL. Berdasarkan hal tersebut menunjukkan bahwa suku bunga SBI yang merupakan variabel makroekonomi mampu menyerap risiko kredit pada perbankan di Indonesia. Jadi sebenarnya mengurangi risiko kredit pada perbankan di Indonesia tidak hanya dapat dikurangi oleh kedua instrumen kebijakan makroprudensial yaitu capital buffer dan GWM LFR saja namun terdapat faktor lain yang justru memiliki pengaruh yang cukup efektif yaitu faktor makroekonomin suku bunga SBI. 


\section{Simpulan}

Hasil penelitian terkait dengan risiko kredit pada industri perbankan go public di Indonesia menujukkan bahwa Capital Buffer, GWM LFR, sebagai instrumen kebijakan makroprudensial dan dan suku bunga SBI sebagai instrumrn makroekonomi berpengaruh positif dan signifikan terhadap risiko kredit perbankan di Indonesia. Penelitian selanjutnya disarankan menambahkan variabel Loan to Value (LTV) serta melakukan penambahan periode penelitian.

\section{Daftar Pustaka}

Abdullah, T., \& Tantri, F. (2012). Bank dan Lembaga keuangan. Raja Grafindo Persada.

Angelini, P., Neri, S., \& Panetta, F. (2011). Monetary and macroprudential policies. Bank of Italy Temi Di Discussione (Working Paper) No, 801.

Anggitasari, A. A., \& Arfinto, E. D. (2013). Hubungan Simultan Antara Capital Buffer dan Risiko. In Dissertation. Fakultas Ekonomika dan Bisnis.

Antipa, P., Mengus, E., \& Mojon, B. (2010). Would Macro-prudential Policies Have Prevented the Great Recession? Banque de France, Mimeo.

Ardely, N. P., \& Syofyan, S. (2016). Efektivitas Kebijakan Makroprudensial Bank Indonesia. Media Ekonomi, 24(1), 49-62.

Dewi, K. P., \& Ramantha, I. W. (2015). Pengaruh Loan Deposit Ratio, Suku Bunga Sbi, Dan Bank Size Terhadap Nonperforming Loan. E-Jurnal Akuntansi, 11(3), 909-920.

Emyliani, F. P., Wulandari, D., Sakarji, S. R., \& Narmaditya, B. S. (2018). Macroprudential Policy on Banking Sector in Indonesia. TRIKONOMIKA, 17(1), $1-6$.

Ferguson, R. W. (2010). Enhancing financial stability and resilience: macroprudential policy, tools, and systems for the future. Group of Thirty (Washington DC). Working Group on Macroprudential.

Goodhart, C. (2011). The Basel Committee on Banking Supervision: a history of the early years 1974-1997. Cambridge University Press.

Greuning, H. van, \& Bratanovic, S. B. (2009). Analyzing banking risk: A Framework for Assessing Corporate Governance and Financial Risk. The World Bank.

Haryanto, S. (2015). Determinan Capital Buffer: Kajian Empirik Industri Perbankan Nasional. Jurnal Ekonomi Modernisasi, 11(2), 108-123.

Lim, C., Columba, F., Costa, A., Kongsamut, P., Otani, A., Saiyid, M., \& Wezel, T. (2011). Wux.(2011) Macroprudential policy: What instruments and How to Use 
Them? Lessons from Country Experiences. IMF Working Papers, 238.

Nuryana, I. (2017). Assessment efektifitas instrumen makroprudensial dalam mengurangi risiko kredit perbankan di Indonesia (Studi Pada Perbankan Go Public Periode 2012-2015). Referensi: Jurnal Ilmu Manajemen Dan Akuntansi, 5(1), 55-68.

Purnawan, M. E., \& Nasir, M. A. (2015). The role of macroprudential policy to manage exchange rate volatility, excess banking liquidity, and credits. Buletin Ekonomi Moneter Dan Perbankan, 18(1), 21-44.

Sintya, K. P. A., \& Santi, S. N. P. (2015). Pengaruh Capital Adequacy Ratio, Bank Size Dan Bi Rate Terhadap Risiko Kredit (Npl) Pada Perusahaan Perbankan. E-Jurnal Manajemen Universitas Udayana, 4(8).

Swaningrum, A., \& Hariwan, P. (2014). Evaluasi Efektifitas Instrumen Makroprudensial dalam Mengurangi Resiko Sistemik di Indonesia. Bandung: Universitas Kristen Satya Wacana.

Tovar Mora, C. E., Garcia-Escribano, M., \& Vera Martin, M. (2012). Credit growth and the effectiveness of reserve requirements and other macroprudential instruments in Latin America. IMF Working Papers. 